\title{
THE NEED FOR ANTITRUST LEGISLATION TAILORED TO THE SPECIFIC CONCERNS OF BANK-NONBANK DIRECTOR INTERLOCKS
}

The United States Supreme Court will soon decide whether section 8 of the Clayton Act ${ }^{1}$ prohibits director interlocks ${ }^{2}$ between a bank and a competimg nonbanking entity. Prior to United States $v$. Crocker National Corp. ${ }^{3}$ the decision under review by the Court, the "other than banks" language of the Clayton Act ${ }^{4}$ had generally been interpreted as exempting imterlocking directorates between banks and nonbanks, regardless of the competition between them, from the Act's general prohibition of interlocks. ${ }^{5}$ In Crocker, however, the Court of Appeals for the Ninth Circuit interpreted the language to mean that the imterlock prohibition applies unless all the corporations are banks. ${ }^{6}$

The Crocker case involved several large banks and insurance companies, ${ }^{7}$ and, if affirmed, promises to have a significant effect on the makeup of boards of directors of banks and insurance companies. At the time of the district court decision in Crocker, forty percent of the insurance company directors in America were bank directors as well. ${ }^{8}$ The Crocker decision is also important because its reasoning inay invalidate all imterlocking directorates between banks and coinpanies outside the imsurance field with which banks coinpete, ${ }^{9}$ as well as the

1. 15 U.S.C. \& 19 (1976).

2. A director interlock exists when two or more corporations have a common individual on their boards of directors.

3. 656 F.2d 428 (9th Cir. 1981), cert. granted sub nom. Bankamerica Corp. v. United States, 102 S.Ct. 2294 (1982).

4. The language of the Clayton Act at issue is contamed in the fourth unnumbered paragraph of section 8:

[N]o person at the same time shall be a director in any two or more corporations, any one of which has capital, surplus, and undivided profits aggregatimg more than $\$ 1,000,000$, engaged in whole or im part in commerce, other than banks, banking associations, trust companies, and common carriers . . . if such corporations are or shall have been theretofore, by virtue of their busmess and location of operation, competitors, so that the elimmation of competition by agreement between thein would constitute a violation of any of the provisions of any of the antitrust laws.

15 U.S.C. $\$ 19$ (1976) (emphasis added).

5. See infra notes $36-39,73-77$ and accompanying text.

6. 656 F.2d at 434 .

7. See infra note 32 and accompanying text.

8. United States v. Crocker Nat'l Corp., 422 F. Supp. 686, 691 (N.D. Cal. 1976).

9. An increasimg variety of industries are now competimg with banks in the credit market. Sears, Roebuck \& Company, the nation's largest retailer, has recently diversified and is offering a 
director interlocks between banks and insurance companies which were involved in the case.

This note examines the Ninth Circuit's interpretation of the Clayton Act. It determines that applying section 8 to a director mterlock between a bank and a coinpeting nonbanking entity is not supported by the statutory language, the legislative history, or the underlymg policy goals of the Act. For this reason, the Supreme Court should overturn the Ninth Circuit decision. Even though such a decision would not immunize bank-nonbank relationships froin antitrust control, ${ }^{10}$ the note recommends new congressional action im the area of bank-nonbank director interlocks. Banks and other compamies such as insurance companies compete in inany markets; Congress did not foresee such competition when it passed the Clayton Act or the other major antitrust acts. ${ }^{11}$ Implementation of new legislation is preferable to judicial action simce Congress could pass a statute tailored to the specific concerns of bank-nonbank interlocks. ${ }^{12}$

\section{The Clayton Act and the Crocker Decision}

The Clayton Act specifically proscribes certain interlocking directorates. ${ }^{13}$ Interlocks may be the source of several economic problems. For example, interlocking directors may dictate discriminatory treatment in the supply of materials and credit. ${ }^{14}$ Interlocks inay give rise to conflicts of interest when competing corporations are served by a coinmon director. ${ }^{15}$ The imterlocks create conduits for the exchange of im-

variety of financial services. If the Crocker decision stands, industry lawyers believe the holding could be applied to an interlocking directorate between a bank and an oil company that issues credit cards. Ruling Would Cut Insurers' Link to Banks, Wall St. J., Oct. 7, 1981, at 29, col. 3.

10. Both the FTC Act and the Slierman Act could be used to attack such interlocks. See 15 U.S.C. $\$ 45$ (1976 \& Supp. IV 1980); 15 U.S.C. \$§ 1-3 (1976). Banks are specifically exempted from the FTC Act, 15 U.S.C. \$ 45(a)(2); however, the Justice Department may use the FTC Act to attack interlocks by bringing suit agaimst the nonbank. See infra notes 92-95 and accompanying text.

The lower court in Crocker specifically refused to comment on whether the FTC Act or the Slierman Act could be used to attack bank-nonbank interlocks. See 422 F. Supp. at 730 n.23.

11. See infra notes 64-67 and accompanying text.

12. The note proposes that Congress pass a statute with a "grandfather" provision-a statute whicl sanctions existing interlocks for several years, see infra note 121 -to avoid the disruption that cliallenges to the numerous interlocking directorships could cause. See supra notes 7-9 and accompanying text.

13. S. REP. No. 698, 63d Cong., 2d Sess. 1 (1914).

14. Travers, Interlocks in Corporate Management and the Antitrust Laws, 46 TEX. L. REv. 819, 832-33 (1968).

15. The conflict arises from the director's access to competitive information including price information. The excluange of price information can be a violation of the Sherman Act. United States v. Container Corp. of Am., 393 U.S. 333, 335-36 (1969). Therefore, the director faces the 
formation ${ }^{16}$ and may result in ineffective management by overburdened direetors. ${ }^{17}$ Finally, interlocks raise the "fear that so much power will be concentrated in so few hands as to be a threat to a free society."18

\section{A. Background and Purpose of the Clayton Act.}

The interlocking directorate was a common characteristic of American industry at the turn of the century. ${ }^{19}$ Two congressional investigations ${ }^{20}$ and a series of writings by Louis Brandeis ${ }^{21}$ provided the impetus for the imclusion of interlock provisions in the Clayton Act. President Woodrow Wilson called for legislation prohibiting both vertical $^{22}$ and horizontal23 director interlocks in a inessage before Congress on January $20,1914 .{ }^{24}$ Despite Wilson's specific reference to

dilemma of being privy to certain information concerning the corporations with which he is associated that the other corporations would like to know, but which he cannot divulge.

16. J. Juran \& J. Louder, The Corporate Director 305 (1966); Johnson, Interlocking Directorates-A Government View, in Responsibilities, Relationships \& Liabilities fOR BOARDS OF DiRECTORS 8 (1976).

17. Louis Brandeis noted this problem in his eloquent attack on the corporate interlock:

The practice of interlocking directorates is the root of many evils. It offends laws human and divine. Applied to rival corporations, it tends to the suppression of competition and to violation of the Sherman law. Applied to corporations which deal with each other, it tends to disloyalty and to violation of the fundamental law that no man can serve two masters. In either event, it tends to inefficiency; for it removes incentive and destroys soundness of judgment.

L. Brandeis, Other People's Money 35 (1933).

18. Travers, supra note 14 , at 833 . If several groups have power, no one group may act in an arbitrary or capricious inanner without another, equally powerful group taking corrective measures. This reasoning underlies the antitrust laws. Market power in many hands is a check on the ability of any one entity to act "unfairly" because the consumer may always turn to another entity that will treat him "fairly."

19. House Comm. on Banking and Currency, Investigation of Concentration of Control of Money and Credit, H.R. Rep. No. 1593, 62d Cong., 3d Sess. (1913) (Report of the Pujo Committee).

20. Id.; House Comm. on Banking and Currency, Investigation of United States Steel CoRP., H.R. Rep. No. 1127, 62d Cong., 2d Sess. (1912) (Report of the Stanley Committee).

21. L. Brandeis, Other People's Money (1933); Brandeis, Breaking the Money Trust, Harper's Weekly, Nov. 22, 1913-Jan. 17, 1914.

22. A vertical director interlock is an interlock between companies situated in a suppliercustomer relationship. See Brown Shoe Co. v. United States, 370 U.S. 294, 323 (1962).

23. A horizontal director interlock is an interlock between companies perfornning similar functions in the production or sale of comparable goods or services. See id. at 334.

24. Wilson said:

[Laws are needed to] effectually prohibit and prevent such interlockings of the personnel of the directorates of great corporations-banks and railroads, industrial, commercial, and public-service bodies-as in effect result in making those who borrow and those who lend practically one and the same, those who sell and those who buy but the same persons trading with one another under different names and in different combinations [vertical relationships], and those who affect to compete in fact partners and masters of some whole field of business [horizontal relationships].

S. REP. No. 698, supra note 13 (emphasis in original). 
vertical interlocks and his express concern with the above problems, ${ }^{25}$ Congress responded in a narrow fashion to the broad subject of interlocks. In the Clayton Act, Congress prohibited only horizontal interlocks, ${ }^{26}$ and alleviated only the impairment-of-coinpetition problem, without addressing problems relating to size and director behavior. ${ }^{27}$ Thus, Congress limited the scope and coverage of the statute within the wider context of the general interlock problein.

\section{B. The Crocker Decision .}

The particular provision of section 8 at issue in Crocker, the fourth paragraph of section 8 , is generally known as the "industrial corporations provision." 28 It contains four limiting clauses that must be satisfied to invoke the interlock prohibition. ${ }^{29}$ First, two or more corporations may not share a director if any one of the corporations has capital, surplus, and undivided profits in excess of $\$ 1,000,000$. Second, the corporations inust be engaged in interstate commerce. ${ }^{30}$ The final clause requires that the corporations be coinpetitors so that elimination of competition by agreeinent between thein would violate another antitrust law. The third clause, phrased as an exception, is the problem clause. It exempts banks, banking associations, trust coinpanies, and common carriers from the purview of the statute. Directorates prohibited by section 8 are per se illegal. ${ }^{31}$

\section{Id.}

26. The language in the statute reads "if such corporations are or shall have been theretofore, by virtue of their business and location of operation, competitors. . . " 15 U.S.C. § 19 (1976). This describes a horizontal relationship. See supra note 23.

The Clayton Act does have a provision, section 10, dealing with vertical interlocks. This section deals specifically with common carriers and is merely regulatory; vertical director imterlocks are not proscribed. 15 U.S.C. $\$ 20$ (1976).

27. The purpose of the Act was "to arrest the creation of trusts, conspiracies, and inonopolies in their incipiency and before consumination." S. REP. No. 698, supra note 13, at 1.

28. See Brief of Defendants-Appellees-Cross-Appellants at 5, United States v. Crocker Nat'1 Corp., 656 F.2d 428 (9th Cir. 1981), cert. granted sub nom. Bankamerica Corp. v. United States, 102 S. Ct. 2294 (1982). For the text of the provision see supra note 4.

29. See 15 U.S.C. $\S 19$ (1976).

30. This requirement is less of a problem today than at the time the Clayton Act was being formulated-a tine when the reacli of the commerce clause was uncertain. Sixty years prior to the passage of the Clayton Act, the Supreme Court held that banking was not cominerce. See Nathan v. Louisiana, 49 U.S. (8 How.) 73 (1850). Therefore, the Congress that formulated the Clayton Act would not have beheved banks were subject to Congress's coinmerce clause power. See Crocker, 422 F. Supp. at 701. Banks now can be regulated under the commerce clause. See United States v. Philadelphia Nat'l Bank, 374 U.S. 321, 336 n.12 (1963).

31. See United States v. Sears, Roebuck \& Co., 111 F. Supp. 614 (S.D.N.Y. 1953). Sears provided the first judicial construction of section 8 . Less than one inonth after this decision, the Supreme Court decided a case dealing with section 8, but did not address the question whether the proper standard of review was a per se rule or a rule of reason. See United States v. W.T. Grant Co., 345 U.S. 629 (1953). Sears has been followed uniformly. See Crocker 656 F.2d at 438; TRW, 
The interlocking directorates attacked in Crocker were held by five individuals, and linked three of the nation's largest banks with four of its largest insurance coinpanies.32 Only the scope of the bank exeinption was at issue. The parties stipulated that the bank defendants and insurance coinpany defendants were coinpetitors in certain inortgage and real estate loans, and that an agreenent between thein to elininate competition would be an antitrust violation. ${ }^{33}$ Thus, the fourth requirement of the statute was satisfied. The defendants conceded that two of the other requirements-having capital, surplus, and undivided profits in excess of $\$ 1,000,000$, and being engaged in interstate coininerce-had also been satisfied. ${ }^{34}$ Given the per se nature of a section 8 violation, ${ }^{35}$ the defendants in effcct admitted that they were not in coinpliance with the Act if the court interpreted the "other than banks" exemption as applying only if all the corporations involved are banks.

1. The Statutory Language. The district court in the Crocker case applied a parallel construction analysis to the language of the industrial corporations paragraph of section 8 , and found it "readily apparent" that the four clauses of the paragraph ${ }^{36}$ "apply to both corporations involved in an interlock, except for the first clause which by its own specific terms inay be satisfied by 'any one of' the two interlocked corporations." 37 The district court noted that the statutory language requires that all interlocked corporations satisfy both the second requirement dealing with interstate commerce and the fourth requirement of a possible impairment of competition. ${ }^{38}$ As evidenced by the statutory language of the first " $\$ 1$ million" clause, Congress was exphicit when restricting application of an element to just one of the parties. No such explicit restriction appears in the language of the "other than banks" exception. Accordingly, the district court held that a par-

Inc. v. FTC, 647 F.2d 942, 947 (9th Cir. 1981); Protectoseal Co. v. Barancik, 484 F.2d 585, 589 (7th Cir. 1973).

32. 656 F.2d at 433. A director of Bank of America National Trust and Savings Association, the nation's largest bank, sat on the board of Prudential Insurance Company. A director of Bankers Trust Company also sat on Prudential's board. Three individuals were directors of Crockcr National Bank and of either the Equitable Life Assurance Society of the United States, Metropolitan Life Insurance Company, or Mutual Life Insurance Company of New York. Id. at 433 n.2.

The potential competition betwcen these concerns was substantial. At the beginning of 1975, the three banks had outstanding real estate loans of $\$ 6.5$ billion; the four insurance companies liad outstanding real estate loans of $\$ 32$ billion. $\mathrm{Jd}$. at 433 .

33. Id.

34. 422 F. Supp. at 688.

35. See supra note 31 and accompanying text.

36. See supra text accompanying notes 29-30.

37. 422 F. Supp. at 690.

38. Id. 
allel construction of the language required that all corporations satisfy the third clause. Therefore, all corporations which are interlocked must be other than banks, banking associations, trust coinpanies, and common carriers for the interlock prohibition to apply. ${ }^{39}$

The Court of Appeals for the Ninth Circuit reversed. The court interpreted the "other than banks" provision as relating back to the immediately preceding paragraphs regulating interlocks between banks. ${ }^{40}$ The court reasoned that because the banking paragraphs apply only to interlocks between banks, only interlocking directorates between banks governed by the banking paragraphs are excluded froin the industrial corporations provision. ${ }^{41}$

Thus, the district court and the court of appeals interpreted the vague language of the statute in different ways, neither of which is clearly correct. The district court interpretation, however, seeins to be the more logical interpretation because the Ninth Circuit's interpretation does not account for all the language of the statute. The statute reads "no person at the saine time shall be a director in any two or more corporations . . . other than banks, banking associations, trust companies, and common carriers . . .."42 Under the Ninth Circuit's construction, only interlocks between common carriers governed by the common carrier provision, section 10,43 should be excluded froin the

39. Id. at 686; Brief of Defendants-Appellees-Cross-Appellants, supra note 28, at 6.

40. 656 F.2d at 434. A part of the "banking" paragraphs is set forth below:

[Para 1]

No private banker or director, officer, or employee of any member bank of the Federal Reserve System or any branch thereof shall be at the same time a director, officer, or employee of any other bank, banking association, savings bank, or trust company organized under the National Bank Act or organized under the laws of any State or of the District of Columbia, or any branch thereof, except that the Board of Governors of the Federal Reserve System may by regulation permit such service as a director, officer, or employee of not more than one other such institution or branch thereof; but the foregoing prohibition shall not apply in the case of any one or more of the following or any branch thereof....

15 U.S.C. $\$ 19$ (1976). The Act then lists seven exceptions to the general prohibition that are not relevant here.

The Depository Institution Management Interlocks Act, 12 U.S.C. $\$ \$ 3201-3207$ (Supp. IV 1980), has been enacted since the institution of the Crocker proceedings. See infra note 95 . The Board of Governors of the Federal Reserve System considers the first three paragraphs of section 8 , the banking paragraphs set forth above, to have been supplanted by this Act. Management Official Interlocks, 12 C.F.R. $\$ 212.7$ (1981).

41. 656 F.2d at 434. This interpretation of the language is not unique. It was also espoused by an administrative law judge in a Federal Trade Commission proceeding. In re Perpetual Fed. Sav. \& Loan Ass'n, 90 F.T.C. 608, 636-37 (1977), vacated on other grounds, 94 F.T.C. 401 (1979). Perpetual is discussed more fully at infra notes 93-102 and accompanying text.

42. 15 U.S.C. $\$ 19$ (1976) (emphasis added).

43. Section 10 is set forth below:

No common carrier engaged in commerce shall have any dealings in securities, supphes, or other articles of commerce, or shall make or have any contracts for construction or maintenance of any kind, to the amount of more than $\$ 50,000$, in the aggregate, in any 
industrial corporations paragraph. The common carrier provision, however, regulates vertical relationships while the industrial corporations paragraph regulates horizontal relationships. If "other than comnon carriers" excludes only those vertical interlocks regulated in section 10, horizontal interlocks between common carriers are not renoved from section 8's prohibitions by this language. It is not necessary to exclude the interlocks regulated by section 10 from the section 8 provision, because the two sections do not purport to regulate the same type of interlock. If the entire "other than" phrase is interpreted consistently with the Ninth Circuit's reasoning, the inclusion of "other than common carriers" has no effect. ${ }^{44}$

2. The Purpose and Policy of the Act. After noting that the language of the act was neither "clear" nor "unequivocal,"4s the Ninth

\footnotetext{
one year, with another corporation, firm, partnership, or association when the said common carrier shall have upon its board of directors or as its president, manager, or as its purchasing or selling officer, or agent in the particular transaction, any person who is at the same time a director, manager, or purchasing or selling officer of, or who has any substantial interest in, such other corporation, firm, partnership, or association, unless and except such purchases shall be made from, or such dealings shall be with, the bidder whose bid is the most favorable to such coininon carrier, to be ascertained by competitive bidding under regulations to be prescribed by rule or otherwise by the Interstate Colnmerce Commission.
}

15 U.S.C. $\$ 20$ (1976).

44. The Crocker court noted the possible inconsistency between the coinmon carrier provision, section 10, and the industrial corporation paragraph of section 8 , but did not attempt to reconcile the two sections other than to say that Congress chose to deal with banks and common carriers differently. 656 F.2d at 443.

A possible interpretation that is somewhat consistent with the Crocker dccision is that the "other than" provision means other than horizontal bank interlocks regulated in the first three paragraphs and other than horizontal common carrier interlocks regulated outside the Clayton Act. This is the position the governinent took in Crocker. "The bank exception was added to avoid inconsistent regulation of bank-bank imterlocks regulated elsewhere in section 8 . The comInon carrier exception was designed to exempt imterlocks between common carriers from regulation because the Interstate Commerce Act had provided adequate safeguards against abuses by those carriers." Brief for the United States at 29, United States v. Crocker Nat'l Corp., 656 F.2d 428 (9th Cir. 1981), cert. granted sub nom. Bankamerica Corp. v. United States, 102 S. Ct. 2294 (1982).

Horizontal imterlocks between common carriers are regulated elsewhere, See 49 U.S.C. $\S 11322$ (Supp. IV 1980) (replacing section 20a(12) of the Interstate Commerce Act, 49 U.S.C. $\S 20 \mathrm{a}(12)$, which was repealed in 1978). Such interlocks were not, howevcr, regulated by the Interstate Commerce Act until 1920, six years after the Clayton Act was enacted. The framers of the Clayton Act, im drafting the "other than common carriers" phrase, could not possibly have relied on a horizontal interlock provision in the Interstate Coininerce Act that had not yet come into existence.

Additionally, this construction requires reference not only to other provisions of the Clayton Act, but also to all other statutory provisions, none specifically mentioned in the Act, which may govern interlocks. While consistent with the court's decision in Crocker, this interpretation of the statutory language is "both straincd and curious." See Brief of Defendants-Appellces-Cross-Appellants, supra note 28 , at 6 .

45. 656 F.2d at 435 . 
Circuit examined the purpose and policy of the Act to determine its meaning. The court relied on the "prophylactic purpose" 46 of the Act to decide that the Act should be construed to prohibit bank-nonbank director interlocks. In its analysis, the court focused on Congress' recognition of "the evil of interlocking directorates" 47 and Congress' desire to strengthen the Sherman Act. ${ }^{48}$ The court also examined cases construing the antitrust laws, and noted that the laws should be "construed liberally," and that "immunity from the antitrust laws is not lightly imphed." "49

Although the general observations of the court are correct, the court ignored the background of the Act itself. ${ }^{50}$ The Clayton Congress sought to control anticompetitive relationships, ${ }^{51}$ yet it excluded from the Act's coverage several anticonipetitive arrangements, such as management and vertical relationships. ${ }^{52}$ Manageinent interlocks, as well as director interlocks, have been criticized by Congress as a vehicle of corporate concentration, ${ }^{53}$ and concentration dampens competition. ${ }^{54}$ A management interlock between a bank and a competing msurance company could threaten the competitive integrity of the credit market. 55 Similarly, vertical interlocks are potentially anticompetive. ${ }^{56}$ The Clayton Act, however, does not proscribe management or vertical interlocks. ${ }^{57} \mathrm{~A}$ harm to competition is not the gravamen of a Clayton Act violation. ${ }^{58}$ The Crocker court ignored this inherent limitation in the nature of the Act.

46. Id. at 440 .

47. Id. at 438 .

48. Id. at 439.

49. Id. at 440-41 (citations omitted).

50. See supra notes 19-27 and accompanying text.

51. See supra notes 26-27 and accompanying text.

52. The industrial corporations paragraph applies to "competitors" [horizontal interlocks], but does not address customer-supplier relationships [vertical mterlocks]. The paragraph is limited also to prohibiting a person from serving as "a director" in two or more coinpeting corporatious. 15 U.S.C. $\S 19$ (1976).

53. See, e.g., Staff of House Antitrust Subcomm. of Comm. of Judiciary, 89th Cong., 1st Sess., Report on Interlocks in Corporate Management 15 (Comin. Print 1965) (management imterlocks); H.R. Rep. No. 627, 63d Cong., 2d Sess. Part 3, 8 (1914) (director interlocks).

54. See supra note 18.

55. The first three paragraphs of section 8 contain evidence of the Clayton Act framers' recognition of the anticompetitive aspect of management mterlocks. These paragraphs proscribe director, officer and employee interlocks. 15 U.S.C. \& 19 (1976).

56. See S. Rep. No. 698, 63d Cong., 2d Sess. 14 (1914).

57. See supra uote 52.

58. There is no empirical evidence nor any judicial findings concerning the coinpetitive effect of bank-nonbank competitor interlocks. The anticipated effect of prolibiting such interlocks is the removal of the danger that anticompetitive effects will result from the imterlocking directorates. See Department of Justice Proposed Consent Judgment and Competitive Impact Statement: United States v. Bankamerica Corp., 41 Fed. Reg. 19,678, 19,679 (1976); Department of Justice 
Thus, the court's rehance on the prophylactic purpose of the Clayton Act in finding bank-nonbank interlocks subject to section 8 was improper. Specific inclusion by the statutory language, not anticompetitive effect, defines the scope of section 8 .

\section{The Legislative History of the "other than banks" Exception.}

Because the language of section 8 of the Clayton Act is unclear, the legislative history of the Act should be examined to help define the meaning of the "other than banks" clause. 59 Unfortunately the legislative history contaims only one specific reference to the "other than banks" language as it would apply to bank-nonbank interlocks.

In a debate on the floor of the House of Representatives, Representative Mann stated that the "other than banks" clause appeared to exempt bank-nonbank interlocks from the Act. ${ }^{60}$ Without the "other than banks" language, Mann believed the proposed Act would regulate these bank-nonbank interlocks. ${ }^{61}$ Mann thus objected that the "other than" clause, which was added by the conference committee, was a substantive change to the draft of the Clayton Act, rather than a clarification. Mann argued that because the House and Senate had not disagreed as to the industrial corporations paragraph, such a change exceeded the authority of the conferees. The Speaker ruled against Mann, ${ }^{62}$ mdicating that the Speaker did not regard the addition of the "other than" clause as a substantive change in the proposed Clayton Act. The Speaker, however, did not specifically address the issue of whether bank-nonbank interlocks were governed by the new industrial corporations provision. ${ }^{63}$

Proposed Consent Judgment and Competitive Impact Statement: United States v. Crocker Nat"l Corp., 41 Fed. Reg. 3754, 3756 (1976).

59. See, e.g., Caminetti v. United States, 242 U.S. 470, 490 (1917).

60. 51 Cong. Rec. 16,272 (1914).

61. Mann believed that prior to the inclusion of the "other than" clause, section 8 prohibited a bank director from also being a director in another company if there was some sort of competition between the corporations. Id. at 16,272-73.

62. Id. at 16,273 .

63. Id. at 16,269-73. The Crocker court brushed aside this House debate because Representative Mann, who was questioning the ineaning of the "other than banks" provision, was an opponent of the interpretation he espoused and the proponents of the statute were not given the opportunity to respond. 656 F.2d at $445-46,445$ n.58. But whereas the Crocker court said Mann first advanced the idea that the "other than banks" provision exempted interlocks between banks and nonbanks on page 16,272 , $i d$. at $445 \mathrm{n} .58$, Mann actually first set out his position on page 16,269 . "What the conferees have done [by adding "other than banks"] is to eliminate from [the imdustrial corporations] section all banking corporations." 51 CoNG. Rec. 16,269. After this statement, the proponents had the opportunity to respond, and did respond prior to the termina- 
This inconclusive House debate is perhaps more important for the insight furnished by another congressman. Representative Sherley indicated that because banks did not compete with industrial corporations they could not be controlled by the industrial corporations provision. ${ }^{64}$ Indeed, at the time the Clayton Act was passed, Congress in all likelihood did not believe it had the ability to regulate banks since the Supreme Court had held that banks did not do business in interstate commerce. ${ }^{65}$ The framers of the Clayton Act did not address horizontal interlocks between banks and nonbanking corporations because at that time there was little competition between banks and nonbanks, ${ }^{66}$ because Congress did not foresee situations in which banks would compete with nonbanking entities sucl as insurance coinpanies or retailers, ${ }^{67}$ and because of perceived constitutional limitations. It is for these reasons that a review of the legislative history ${ }^{68}$ is unproductive.

\section{Post-1914 Interpretations.}

Since the purpose and policy of the Act are vague and its legislative history is inconclusive, it is helpful in determining its meaning to

tion of the debate, calling Mann's objection "purely and entirely technical" and suggesting that clarity was the purpose behind including the clause. Id. at 16,271 .

64. Id. at 16,272 . The Crocker court alluded to this insight, characterizing it as a "failure to anticipate that banks might soinetimres compete with nonbanking corporations." 656 F.2d at 445 n.58.

65. See supra note 30.

66. See generally Wallich and Vervel, Evolution in Banking Competition, EcoN. REV. FED. RES. BANK OF RICHMOND 3 (March/April 1981); Light, Increasing Competition between Financial Institutions, Econ. Perspectives Fed. Res. Bank of ChiCago, 25, 27 (May/June 1977).

As late as 1963, the Supreine Court was still of the opinion that the cluster of products and services offered by banks composed a distinct line of commerce. United States v. Philadelphia Nat'l Bank, 374 U.S. 321, 356-57 (1963). While it was conceded that other entities were in the business of supplying credit, and therefore "inore or less in coinpetition with commercial banks," id. at 326 n.5, the prevailing theine was that the cluster of banking products and services is "so distimctive that [it is] entirely free of effective competition from products or services of other financial institutions. . . ." Id. at 356.

67. See supra note 9.

68. In addition to Mann's comments, see supra notes 60-63 and accoinpanying text, the legislative history contaims one other reference to bank-nonbank interlocks. In hearings before the House Committee on the Judiciary during the Clayton Act's initial legislative stage, specific reference was made to bank-insurance company interlocks. Hearings on Trust Legislation Before the House Comm. on the Judiciary, 63d Cong., 2d Sess. 823, 925 (1914). The einphasis, however, was not on the competitive relationship between these entities, but rather on an aversion to having large concerns share directors. "I think there is a grave question as to whether a director in a great hife insurance company should be a director in a bank." Id. at 823 (remark by Mr. Untermyer, counsel for the Pujo Committee). Such concern was not instigated by competition between banks and insurance companies, but by the fact that both are a type of "financial" concern and often have common places of business. Id. at 925 (remark by Louis Brandeis). Competition between banks and noubanks was not a consideration. 
examine the way the Act has been interpreted in the past. Although the courts are, of course, final arbiters of the meaning of a statute, the Supreme Court has on many occasions been guided by nonjudicial views. ${ }^{69}$ The Crocker court emphasized that reference to the views of a subsequent Congress is an unsound method of inferring the intent of an earlier Congress, ${ }^{70}$ and therefore dismissed references to congressional interpretations subsequent to the Clayton Act's passage. ${ }^{71}$ The court, in cursorily dismissing the subsequent congressional views, failed to see the value of these later references. The value is not as an indication of the Clayton Act Congress' origimal intent, but ratler as interpretations of how the Clayton Act applies to new situations not contemplated by that Congress. ${ }^{72}$

The Act has always been interpreted in the past as not applying to bank-nonbank imterlocks. For sixty-five years, Congress and other governmental bodies lave interpreted the Clayton Act as not prohibitmg interlocking directorates between a bank and a nonbanking competitor. A 1950 Federal Trade Commission report concluded that section 8 leaves interlocking directorates between industrial and commercial corporations and financial institutions uncliallenged. ${ }^{73}$ Various congressional committees and subcommittees have reached a similar conclusion. ${ }^{74}$ Crocker is the first attack on a bank-nonbank interlock in sixty years, mdicating that the Justice Department apparently did

69. See, e.g., Continental T.V. v. GTE Sylvania, 433 U.S. 36, 47-48 \& n.13 (1977). Of course, the Court has often ignored such views.

70. 656 F.2d 428, $446,447$.

71. "[O]nly the views of the Congress that enacted the Clayton Act are relevant." Id. at 447.

72. See supra notes 65-67 and accompanying text.

73. The Report of the Federal TRADE Comm. ON INTERlocking Directorates, H.R. Doc. No. 652, 81st Cong., 2d Sess. 10 (1950). The government in Crocker claimed that the phrase "financial institutions" was used throughout the report to refer to both insurance counpanies and banks. Brief for the United States, supra note 44, at 31 n.27. The court of appeals failed to discuss the government's claim. The context in which this term was used, however, is not consistent with the government's assertion. In any event, a noninsurance entity competing with a bank would be exempt from section 8 under the FTC's interpretation.

74. See Staff of Subcomm. on Reports, Accountino and Management of the Sen-

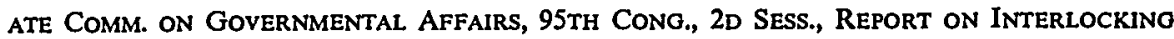
Directorates Amono the Major U.S. CoRps. 122 (Comm. Print 1978) (emphasizing the number of bank-msurance interlocks, not directly commenting on validity); STAFF OF THE SUBCOMm. on Domestic Finance of the House Comm. on Banking and Currency, 90Th CONG., 1st SEsS., Control of Commercial Banks and INTERlocks AMONo Financial INSTITUtions (Comm. Print 1967), reprinted in STAFF of House CoMm. ON Bankino and CuRRENCY, 90TH CONG., 2D SESS., I REPORT ON COMMERCIAL BANKS AND THEIR TRUST ACTIVITIES: EMERging INFluence ON THE AMERICAN EConomy 921 (Comm. Primt 1968) ("the [Clayton Act] does not apply to interlocks between commercial banks and coinpeting financial institutions, such as . . . insurance companies") [hereinafter cited as CONTROL OF COMMERCIAL BANKS]; STAFF OF SubCOMm. ON ANTITRUST OF THE HOUSE COMM. ON THE Judiclary, 89TH CoNG., 1st Sess., Report on Interlocks in Corporate MaNagement 25, 26 (Comm. Print 1965) ("no prohibi- 
not consider such interlocks a violation of the Clayton Act. ${ }^{75}$ Finally, commentators have read section 8 as not prohibiting interlocks between a banking institution and a business corporation. ${ }^{76}$ These explicit and implicit interpretations of section 8 have led to "widespread reliance on the assumption that the statute does not cover [bank-nonbank] interlocks." "77

A plain reading of the statutory language does not support the Crocker court's holding that such interlocks are prohibited by the Act. Neither does the pohicy of the Act support such a conclusion. The legislative history of the Act is at best inconclusive as to the "other than banks" provision and its application to bank-nonbank competitor interlocks, and more probably does not address the issue at all since nonbank competitors were not a prominent market force at the time of the Act's inception. At present, Congress is presumably aware that bankinsurance company interlocks are potentially anticoinpetitive, and that regulation or prohibition of these interlocks may be desirable. For the courts to take action and use section 8 as a means to this regulatory end, however, is nothing short of judicial revision of the industrial corporation provision.

\section{Alternative Approaches for Attack: The FTC AND SHERMAN ACTS}

The Justice Departinent chose to prosecute under the Clayton Act in the Crocker case although the Clayton Act was not the only statute available. Both the FTC Act ${ }^{78}$ and the Sherman Act ${ }^{79}$ may apply to

tion in the statute against . . . interlocks between banking organizations and other types of corporations").

75. The Clayton Act was passed in 1914. The government initiated proceedings that resulted in the Crocker case in 1975. Since 1975, a bank-savings and loan interlock has been attacked, but not under section 8. See In re Perpetual Fed. Sav. \& Loan Ass'n, 90 F.T.C. 608 (1977), vacated on other grounds, 94 F.T.C. 401 (1979). See infra notes $93-102$ and accompanying text.

It is possible, however, that the absence of bank-nonbank competition was responsible for soine of this "hands off" treatment by the Justice Departinent. But see CONTROL OF COMMERCial BANKs, supra note 74.

76. See, eg., 16C J. von Kalinowski, Business Organizations, ANTItrust Laws and TRADE Regulation \$21.03, p. 21-14 (1969 \& 1982 Supp.); 2 S. Kanwit, Federal TRade ComMISSION \& 18, 18-3, 18-4 (1979).

77. United States v. Crocker Nat'l Corp., 656 F.2d at 456 (Kennedy, J., dissentimg). This widespread reliance is evidenced by the large nuinber of bank-insurance coinpany interlocks. See supra note 8 and accompanying text.

78. 15 U.S.C. $\$ 45$ (1976 \& Supp. IV 1980). For an application of the FTC Act to interlocks, see, e.g., In re TRW, Inc., 93 F.T.C. 325 (1979), affd, TRW, Inc. v. FTC, 647 F.2d 942 (9th Cir. 1981); In re Kraftco Corp., 92 F.T.C. 416 (1978).

79. 15 U.S.C. $\$ \$ 1-3$ (1976 \& Supp. IV 1980). The Sherman Act may be used to attack the interlock as either a restraint of trade or an atteinpt to monopolize. According to one commentator, "section 5 of the FTC Act and section 1 of the Sherman Act, when used in conjunction with 
bank-nonbank director interlocks. Should the Supreıne Court reverse the Crocker decision, these Acts will be the only available method for attacking Crocker-type interlocks. An examination of the applicability of these Acts to cases such as Crocker is worthwhile as use of these Acts may create several problems.

First, use of either the FTC or Sherman Acts might well have changed the result in the Crocker case. Although it is not altogether clear, the standard of review under both Acts when applied to interinterlocks inay be rule of reason and not per se; thus, to attack the interlocks successfully, the government would have to show anticompetitive effects. The difficulty of showing such effects may have been one reason that the government chose to use the Clayton Act in Crocker. Second, use of the FTC Act creates jurisdictional problems simce banks are exeinpt froin FTC control. This problem, however, does not appear to be insurmountable.

Both the FTC and Sherman Acts are cumbersome to apply to bank-nonbank director interlocks because both statutes are of general apphicability while bank-nonbank director interlocks are a comparatively specialized area of concern. The problems with these Acts may well be a coinpelling force in persuading Congress to act should the Supreine Court reverse Crocker.

\section{A. FTC Act and Bank-Nonbank Interlocks.}

In 1914, President Wilson recommended that a governmental commission be created to supplennent the judicial process in regulating and controlling business. ${ }^{82}$ The Federal Trade Commission was established following this recommendation to aid the judieiary in controlling unreasonable practices by mvestigating and dissemmatimg information about business conditions. ${ }^{83}$ Section 5 of the FTC Act attempts to achieve the control of unreasonable business practices by prohibiting "[u]nfair methods of coinpetition in or affecting commerce, and unfair or deceptive acts or practices im or affectimg commerce. . . ."84 Interlocking directorates were specifically mentioned in the legislative

section 8 of the Clayton Act, form a statutory framework that provides for complete and effective regulation of all imterlocks, no matter what form they take." Note, Interlocking Dircctorates and Section 8 of the Clayton ACt, 44 ALB. L. Rev. 139, 160 (1979).

80. See infra notes $96-102$ and $110-119$ and accompanyimg text.

81. See infra notes $92-95$ and accompanying text.

82. See 51 Cong. Rec. 1978-79 (1914).

83. See generally Kruse, Deconcentration and Section 5 of the Federal Trade Commission Act, 46 Geo. WASH. L. Rev. 200, $211-24$ (1978); Note, Section 5 of the Federal Trade Commission Acl: A Source of Protection for Competitors and Consumers, 12 B.C. INDUS. \& CoM. L. REv. 982 (1971).

84. 15 U.S.C. § $45(a)(1)$ (Supp. IV 1980). 
history as an example of unfair competition, ${ }^{85}$ and the FTC has successfully used this provision to attack director interlocks. ${ }^{86}$

1. Applicability of the FTC Act to Bank-Nonbank Interlocks. Under section 5 of the FTC Act, the FTC has the power to suppress as an unfair method of competition any practice that runs counter to the public policy of the Clayton Act. ${ }^{87}$ The Commission "considers public values beyond simply those enshrined in the letter or encoinpassed in the spirit of the antitrust laws" in determining whether a practice is deceptive or unfair. ${ }^{88}$ Nevertheless, the question of whether section 5 of the FTC Act may reach an interlock that violates the policy of the Clayton Act, but that technically does not violate section 8, has been expressly left open by both the Commission and the Ninth Circuit. ${ }^{89}$ In light of the Supreme Court's position that the FTC Act is violated when conduct conflicts with the basic policy of the Clayton Act, even though such conduct may not actually violate the Act, 90 bank-nonbank competitor director interlocks should not be excluded froin the FTC Act's coverage merely because technically they do not violate section 8 of the Clayton Act.91

85. S. Rep. No. 597, 63d Cong., 2d Sess. 13 (1914).

86. See, e.g., In re Claude M. Blair, 96 F.T.C. 184 (1980); In re British Oxygen Co., 86 F.T.C. 1241 (1975).

87. Fashion Originators' Guild of Am. v. FTC, 312 U.S. 457 (1941).

88. FTC v. Sperry \& Hutchinson Co., 405 U.S. 233, 244 (1972).

89. The FTC Act registers all violations of the Clayton and Sherman Acts. See FTC v. Motion Picture Advertising Serv. Co., 344 U.S. 392, 394-95 (1953). The adıninistrative law judge in the first Krafico proceeding retied on this rule in sidestepping the question whether a court could, through the FTC Act, reach a director interlock that was not a violation of the Clayton Act. See In re Kraftco Corp., 89 F.T.C. 46,58 n.26, rev'd and remanded sub nom. SCM Corp. v. FTC, 565 F.2d 807 (2d Cir. 1977), on remand, 92 F.T.C. 416 (1978) (original order reimposed). The judge found that a section 8 violation existed, so under the Motion Picture Advertising Service rule, section 5 of the FTC Act had also been violated. Id. (citing Motion Picture Advertising Serv. Co., 344 U.S. at 394-95).

In the TRW proceedings, both the Conmission, 93 F.T.C. at 386 n.22 (1979), and the Ninth Circuit, 647 F.2d at 945 n.1 (9th Cir. 1981), avoided the question; again, because section 8 had been violated.

90. See, e.g., United States v. American Bldg. Maintenance Indus., 422 U.S. 271, 279 n.7 (1975); FTC v. Brown Shoe Co., 384 U.S. 316, 321 (1966); Atlantic Ref. Co. v. FTC, 381 U.S. 357, 369 (1965).

91. Using section 5 of the FTC Act to attack director interlocks is analogous to using section 5 to combat merger activity that night be violative of section 7 of the Clayton Act. It has been suggested that characterizing these mergers as unfair acts under section 5 would obviate the necessity of showing anticompetitive effects required under section 7. Carstensen \& Questal, The Use of Section 5 of the Federal Trade Commission Act to Attack Large Conglomerate Mergers, 63 CoRNELL L. REv. 841, 841 (1978). With respect to interlocking directorates, section 5 would obviate the need for fulfilling the specific requirements of section 8 . 
The obvious impediment to use of section 5 to challenge banknonbank competitor interlocks is that banks are not subject to FTC jurisdiction. ${ }^{92}$ In proceedings before the FTC in In re Perpetual Federal Savings \& Loan Association,,$^{93}$ however, section 5 was successfully used to attack bank-savings and loan director interlocks. The administrative law judge in Perpetual reasoned that, while banks are exeinpt from FTC jurisdiction, the FTC inay still challenge any nonexeinpt corporation with which an exempt firm is interlocked. ${ }^{94}$ The directorate interlocks of the exempt firm may thereby be effectively controlled. Thus, through the use of section 5, the FTC can regulate interlocks between banks and nonexempt competitors, and thereby circuinvent the jurisdictional limitation by controlling interlocks of corporations within the Commission's jurisdiction. ${ }^{95}$

2. The Standard of Review Under the FTC Act. In Perpetual, the Commission was able to persuade the administrative law judge to use a per se standard of review. ${ }^{96}$ Thus, evidence of an adverse effect on competition was unnecessary to find those bank-savings and loan interlocks an unfair practice violating section 5. Because the section 5 viola-

92. 15 U.S.C. $\$ 45(a)(2)$ (Supp. IV 1980).

93. 90 F.T.C. 608 (1977), vacated on other grounds, 94 F.T.C. 401 (1979).

In 1968, 56\% of savings and loans had interlocks with coinmercial banks. Herman, Confict of Interest in the Savings and Loan Industry, in 2 STUDY OF THE SAVINGS AND LOAN INDUSTRY 763, 871 \& $\mathrm{n} .4$ (1969). The FTC recognized the pervasiveness of these interlocks and supported a short grace period for compliance as an appropriate policy. Federal Trade Commission Statement of Pohicy: Interlocking Directorates, 41 Fed. Reg. 35,573, 35,574 (1976).

94. 90 F.T.C. at 638. See Halverson, Interlocking Directorates - Present Antitrust Enforcement Interest Placed in Proper Analytical Perspective, 21 VILL. L. Rev. 393, 405 n.60 (1976) (" $[T]$ here is no apparent reason why the FTC could not challenge the director and any nonexempt commercial corporations with which the exempt firms are interlocked.").

This reasoning also applies to bank-insurance company interlocks such as those found in Crocker because the FTC lias jurisdiction over insurance companies. See 15 U.S.C. \& 45(a)(2) (Supp. IV 1980).

95. The decision in Perpetual was vacated, 94 F.T.C. 401 (1979), when section 5 of the FTC Act was amended to exempt savings and loans froin FTC jurisdiction. See 15 U.S.C. § 45(a)(2) (Supp. IV 1980). The reasoning in Perpetual that allowed section 5 attacks on interlocks between exeinpt and nonexempt corporations was not disturbed, however, and remains valid.

Prior to the above amendinent, Congress enacted the Depository Institution Managenent Interlocks Act (DIMIA), 12 U.S.C. $\$ \$$ 3201-3207 (Supp. IV 1980), which regulates bank-savings and loan interlocks. Id. \& 3202. Concern over interlocks between depository institutions left unregulated by the Clayton Act was one reason for the legislation. H.R. REP. No. 1383, 95th Cong, 2d Sess. 14, reprinted in 1978 U.S. CODE CONG. \& AD. News 9273, 9286.

In the legislative history of DIMIA, one congressman expressed an imteresting opinion relevant to Crocker: "While the bill provides important prohibitions against interlocks among depository institutions, it fails to address the very real problems of interlocks between depository and nondepository institutions-essentially banks and insurance companies." Id. at 201, 1978 U.S. CODE CONG. \& AD. News 9332 (additional views of Rep. St. Germain).

96. 90 F.T.C. at 657. 
tion was predicated on section 8 of the Clayton Act, a per se statute, 97 the Commission reasoned that the standard of review for the underlying violation should dictate the standard of review of the FTC Act violation. "Where Section 5 is employed to adopt the policy of a per se statute, the per se standard remaims applicable."98

The FTC's invocation of a per se rule of liability for section 5 was unwarranted in this context for two reasons. First, the Commission improperly relied on the Clayton Act as the underlying basis for the section 5 claim because bank-nonbank interlocks are exempted froin section 8 coverage by the "other than banks" language. Thus the banksavings and loan imterlock attacked was not technically a section 8 violation. ${ }^{99}$ If the interlock does not fit specifically within section 8 per se confines, it seems inappropriate to use section 5 to bootstrap a per se rule of liability onto interlocks that fall outside the reach of section 8.100

Second, the Commission incorrectly relied on the Second Circuit case of Grand Union Company v. FTC ${ }^{101}$ for the proposition that where section 5 adopts the policy of a per se statute, a per se standard is to be enployed. The court in Grand Union used a per se rule of liability for section 5 to reach an "integral part" of a per se violation. ${ }^{102}$ Yet, a practice that violates an "integral part" of a per se statute is not synonymous with a practice that "violates the policy" of a per se statute, as an integral part is but a subset of a statute's broader policy. Perpetual inappropriately expanded the Grand Union reasoning to graft a per se standard of review onto the section 5 prosecution.

Since the Perpetual decision is incorrect, whether evidence of adverse effects on competition will be necessary in future section 5 attacks on bank-nonbank competitor interlocks is uncertain. ${ }^{103}$ Assuming that bank-nonbank competitor interlocks are not covered by section 8 of the Clayton Act, however, it is illogical to graft a section 8 per se rule of liability onto section 5 when section 5 is used to attack the interlock.

97. See Protectoseal Co. v. Barancik, 484 F.2d 585, 589 (7th Cir. 1973).

98. 90 F.T.C. at 657.

99. The bank-savings and loan interlock arguably violated the policy of the Clayton Act. See supra text accompanying notes $45-57$.

100. Cf. 90 F.T.C. at $645-48$ (Collier, Comm'r, dissenting) (since a factual foundation for inferring public injury is missing and interlock falls outside the section 8 statutory per se rule, case should be remanded for further proceedings).

101. 300 F.2d 92 (2d Cir. 1962).

102. Id. at 99. The underlying violation in Grand Union was of section 2(d) of the Clayton Act, as amended by the Robinson-Patman Price Discrinination Act, 15 U.S.C. $\S 13$ (d) (1976). Sectiou 2(d) is a per se statute. FTC v. Simplicity Pattern Co., 360 U.S. 55, 65, 67 n.11 (1959).

103. Of course, should the Supreme Court affirm Crocker, for all practical purposes the question would be moot. 
Per se status is cautiously granted. ${ }^{104}$ Therefore section 5 should not enjoy the benefit of per se application when it is next used to attack interlocks falling outside specific statutory prohibitions. Indeed, the Justice Departinent and the FTC inay have recognized the force of this reasoning when filing suit in the Crocker case, and nnay, therefore, have chosen to use section 8 of the Clayton Act. Froin a regulator's viewpoint, then, section 8 is a nnore economical tool than section 5 of the FTC Act since section 8 avoids the difficult showing of anticompetitive effects. ${ }^{105}$

104. The Supreme Court recently spoke to the granting of per se status, stating that "the established position [is] that a new per se rule is not justified until the judiciary obtains considerable rule of reason experience with the particular type of restraint challenged." Arizona v. Maricopa County Medical Soc'y, 102 S.Ct. 2466, $2476 \mathrm{n} .19$ (1982). With virtually no case law outside of the statutorily per se section 8 of the Clayton Act, the granting of per se status when other provisions are used to attack interlocks is highly unlikely. The Court has spoken more specifically to the use of a per se standard of review:

Per se rules thus require the Court to unake broad generahizations about the social utility of particular commercial practices. The probability that anticompetitive consequences will result from a practice and the severity of those consequences inust be balanced agamst its procompetitive consequences. Cases that do not fit the generalization may arise, but a per se rule refiects the judgment that such cases are not sufficiently common or important to justify the time and expense necessary to identify them. Once estabhished, per se rules tend to provide guidance to the business community and to minimize the burdens on litigants and the judicial system of the more complex rule-of-reason trials, but those advantages are not suficient in themselves to justify the creation of per se rules. If it were otherwise, all of antitrust law would be reduced to per se rules, thus introducing an unintended and undesirable rigidity in the law.

Continental TV, Inc. v. GTE Sylvania, Inc., 433 U.S. 36, 50 n.16 (1977) (citations omitted).

105. Using section 8 also avoids problems with the bank exemption to the FTC Act. See supra notes 92-95 and accompanying text.

Regulating bank-nonbank coinpetitor interlocks through the FTC Act raises McCarran-Ferguson Act issues, 15 U.S.C. $\$ \S 1011-1015$ (1976). Nevertheless, it is doubtful that the McCarranFerguson Act would have precluded application of the FTC Act in Crocker. The district court and court of appeals agreed that the interlock was not excluded from the Clayton Act by the McCarran-Ferguson exemption. See 422 F. Supp. at 706; 656 F.2d at 452.

The McCarran-Ferguson Act was passed in response to the Supreme Court's holding in Umited States v. South-Eastern Underwriters Ass'n, 322 U.S. 533 (1944), that the business of insurance could be interstate commerce and thereby subject to the cominerce clause power of Congress. Previously, it had been assumed that the issuance of insurance pohicies across state lines was not interstate commerce, see Paul v. Virginia, 75 U.S. (8 Wall.) 168 (1868), and that the antitrust laws were mapplicable to insurers. The Act placed a moratorium on the application of the antitrust laws to the insurance industry. See Reply Brief and Brief in Response for the United States at 35, United States v. Crocker Nat'l Corp., 656 F.2d 428 (9th Cir. 1981), cert. granted sub nom. Bankamerica Corp. v. United States, 102 S. Ct. 2294 (1982).

The McCarran-Ferguson Act allows federal regulation of the "business of insurance" only to the extent that it is not regulated by the states. 15 U.S.C. $\$ 1012(b)$ (1976). The Sherinan Act, Clayton Act, and FTC Act are similarly restricted in application to insurance companies. "[The three acts] shall be apphicable to the business of insurance to the extent that sucl business is not regulated by State law." Id. The Crocker court found that the law of neither New York nor New Jersey (the home states of the challenged banks and insurance conipanies involved) regulated bank-insurance company interlocks. 656 F.2d at 453. 


\section{B. The Sherman Act and Bank-Nonbank Interlocks.}

Interlocking directorates may be attacked under sections 1 and 3 of the Sherman Act, which prohibit contracts, combinations, or conspiracies in restraint of trade, ${ }^{106}$ and under section 2 of the Act, which prohibits monopolies and attempts to monopolize. ${ }^{107}$ Government antitrust actions under the Slerman Act terminated by consent decrees including prohibitions on interlocks between competing corporations, are evidence of the potential success of this strategy. ${ }^{108}$ Additionally, the Sherman Act does not encounter the jurisdictional problems of FTC Act application to bank-nonbank interlocks. ${ }^{109}$

Whether the standard of review for an action brought under the Sherman Act makes bank-nonbank competitor interlocks per se illegal or necessitates the showing of anticompetitive effects is uncertam. This specific question has not been addressed by the courts. Although the Crocker court stated that interlocks are per se illegal under the Sher-

Even if insurance company interlocks are regulated by state law, however, the Act does not apply if the selection of directors is not considered "the business of insurance." The Supreme Court significantly narrowed the definition of "the business of insurance" in Group Life \& Health Ins. Co. v. Royal Drug Co., 440 U.S. 205 (1979). See Note, The Definition of "Business of Insurance" Under the McCarran-Ferguson Act After Royal Drug, 80 CoLuM. L. REv. 1475, 1479-81 (1980). The Court clarified its holding in Royal Drug in Union Labor Life Ins. Co. v. Pireno, 102 S.Ct. 3002 (1982), identifying three criteria relevant in determining what is the business of insurance: "FFirst, whether the practice has the effect of transferring or spreading a policyholder's risk; second, whether the practice is an integral part of the policy relationship between the insurer and the insured; and third, whether the practice is limited to entities within the insurance industry." Id. at 3009.

In competing with banks or sharing directors, insurance companies are not engaging in the "busmess of imsurance" as defined in Royal Drug and Pireno. Thus, it seems doubtful that the McCarran-Ferguson Act would ever preclude application of the FTC Act (or the Sherman or Clayton Acts) in any interlocking directorate case involving a bank and an insurance company. Cf. In re John Hancock Mut. Life Ins. Co., 92 F.T.C. 383 (1978) (use of FTC Act to regulate interlocking directorates among insurance companies; consent order filed).

106. 15 U.S.C. $\S \S 1,3$ (1976).

107. 15 U.S.C. $\$ 2$ (1976).

McCarran-Ferguson questious will also arise if the Sherman Act is used to challenge bankimsurance company competitor interlocks, because the McCarran-Ferguson Act restricts the application of the Sherman Act. 15 U.S.C. \& 1012(b) (1976). The identical analysis included in the discussion of the FTC Act applies in Sherman Act cases, see supra note 105; thus, the McCarranFerguson Act exemption does not prohibit the regulation of bank-insurance counpany interlocks through sections 1, 2, or 3 of the Sherman Act.

108. See, e.g., United States v. General Motors Corp.; 1965 Trade Cas. (CCH) ๆ71,624 (E.D. Mich. 1965); United States v. True Temper Corp., 1959 Trade Cas. (CCH) ๆ69,441 (N.D. Ill. 1959); United States v. Linen Supply Inst., 1958 Trade Cas. (CCH) I 69,120 (S.D.N.Y. 1958); United States v. National Cranberry Ass'n, 1957 Trade Cas. (CCH) I 68,850 (D. Mass. 1957).

109. Sherman Act decrees have also extended the interlock prohibition to officers, agents, and employees. See cases cited supra note 108. 
man Act, ${ }^{110}$ the authority cited by the court supports per se illegality for director interlocks under the Clayton Act, not the Slierman Act."11 Additionally, courts have not applied a per se standard under the Sherman Act when reviewing imterlocks. ${ }^{112}$ Thus, the Crocker court's imterpretation of the Sherman Act standard of review is unsupported by case law.

The prevailing standard of review under the Sherman Act is a "rule of reason." 113 This standard requires the factfinder to weigh all the circumstances of a case to determine whether a restrictive practice should be prohibited as an unreasonable restraint on trade.114 Only plainly anticompetitive activities are per se illegal under the Sherman Act. ${ }^{115}$ When the Supreme Court enumerated per se violations of the Sherman Act in White Motor Co. v. United States, ${ }^{116}$ it did not include imterlocking directorates in that list. ${ }^{117}$

110. "Interlocking arrangements between competing corporations threaten the basic purpose of the Sherman Act and are therefore treated as illegal per se." United States v. Crocker Nat'1 Corp., 656 F.2d at 438 (dictum).

111. The court cited TRW, Inc. v. FTC, 647 F.2d 942, 947 (9th Cir. 1981) and United States v. Sears, Roebuck \& Co., 111 F. Supp. 614, 616-17 (S.D.N.Y. 1953) in support of its assertion of per se illegality. In TRW the court discussed section 8 of the Clayton Act and concluded that proof of actual anticompetitive effect is not required. 647 F.2d at 947 . In Sears the court observed that an agreement to fix prices between competitors would be a per se violation of the Sherman Act. 111 F. Supp. at 616. But any per se rule as applied to imterlocking directorates is mentioned only in connection with section 8 of the Clayton Act. See id. at 616-17.

112. See United States v. Morgan, 118 F. Supp. 621,708 (S.D.N.Y. 1953).

113. Continental T.V., Inc. v. GTE Sylvania Inc., 433 U.S. 36, 49 (1977) (citing Standard Oil Co. v. Uniited States, 221 U.S. 1 (1911)).

114. The classic statement of the rule of reason was made by Mr. Justice Brandeis:

The true test of legahity is whether the restraint imposed is such as merely regulates and perhaps thereby promotes competition or whether it is such as may suppress or even destroy competition. To determime that question the court inust ordmarily consider the facts peculiar to the business to which the restraint is applied; its condition before and after the restraint was imposed; the nature of the restraint and its effect, actual or probable. The history of the restraint, the evil beheved to exist, the reason for adopting the particular remedy, the purpose or end sought to be attained, are all relevant facts. This is not because a good intention will save an otherwise objectionable regulation or the reverse; but because knowledge of intent inay help the court to interpret facts and to predict consequences.

Chicago Bd. of Trade v. United States, 246 U.S. 231, 238 (1918).

115. See National Soc'y of Professional Eng'rs v. United States, 435 U.S. 679, 692 (1978). If the practice appears to be one that always or almost always tends to restrict competition and decrease output, it will receive per se treatınent. Broadcast Music, Inc. v. CBS, Inc., 441 U.S. 1, 19-20 (1979).

116. 372 U.S. 253 (1963).

117. The list of per se violations of the Sherman Act consisted of four items: 1) sale of unpatented products tied to patented article; 2) agreement between competitors to divide markets; 3 ) group boycotts; and 4) horizontal and vertical price-fixing arrangements. Id. at 259-60.

This list of per se Sherman Act violations was not expressly exclusive. The Court, however, viewed the law in these areas as so well developed that the anticompetitive effects could be assumed without the necessity of proof. The law surrounding director imterlocks and the Sherman Act is not well developed. Interlocks do not share characteristics with the per se violations the 
Exchange of competitive information may be per se illegal under the Sherman Act.118 But while the interlocking directorate may increase the possibility of such an exchange, ${ }^{119}$ only that activity, and not the underlying interlock, should be given Sherman Act per se treatinent. Unless an interlock is demonstrably part of a inore general plan that is per se violative of the Sherman Act, evidence of an anticompetitive effect from the interlock should be required to establish a Sherman Act violation.

Sections 1, 2, and 3 of the Sherman Act and section 5 of the FTC Act may be used against bank-nonbank competitor interlocks. Unlike section 8 of the Clayton Act, however, the FTC Act encounters jurisdictional probleins, and both the Sherman and FTC Acts may require evidence of anticoinpetitive effects to establish a violation. In light of these differing standards of review, use of the Clayton Act to challenge bank-nonbank interlocks could change the result in inany cases because of the difficulty of showing anticompetitive effects. Should the Supreine Court overturn Crocker, these problems would be of immediate concern.

\section{LEgisLative RESPONSE}

Even if the Supreme Court affirms Crocker, legislation crafted specifically to deal with the relationships between various types of financial institutions and bank-nonbank competitor interlocks should be enacted ${ }^{120}$ since Crocker prohibits a practice previously thought ex-

Supreme Court enumerated and therefore should not be accorded per se status. See supra note 104.

118. See United States v. Container Corp. of Am., 393 U.S. 333, 337 (1969). But see United States v. Citizens and S. Nat'l Bank, 422 U.S. 86, 113 (1975).

119. In re Perpetual Fed. Sav. \& Loan Ass'n, 90 F.T.C. 608, 623 (1977), vacated on other grounds, 94 F.T.C. 401 (1979).

120. Congress should take action to clarify, at least, section 8 of the Clayton Act. The efficacy of section 8 of the Clayton Act as a regulatory tool to prohibit interlocks has been questioned by commentators. See, e.g., Jacobs, Interlocks, 29 A.B.A. ANTITRust SeCTION 204, 207 (1965); Kramer, Interlocking Directorships and the Clayton Act After 35 Years, 59 YALE L.J. 1266, 1274 (1950). In the words of a vigorous proponent of more comprehensive legislation, section 8 "is as full of holes as swiss cheese. Its shortcounings have been highlighted again and agam. . . ." 110 CONG. REC. 5767 (1964) (remarks of Rep. Celler).

This situation has not gone unnoticed, and there have been several congressional atteinpts to strengthen the Clayton Act by passing legislation to bar bank-nonbank interlocks. See Umited States v. Crocker Nat'l Corp., 656 F.2d at $446 \&$ n.61. At least one of these proposed bills would have specifically prohibited bank-insurance company interlocks. The Banking Reform Act of 1971: Hearings Before the Comm. on Banking and Currency, House of Representatives, 92d Cong., Ist Sess. 1-9 (1971). As of yet, however, these attempts have failed, and the government has been reluctant to use the Act. See, e.g., Staff of Senate Subcomm. on Reports, Accounting and Management of the Comm. on Governmental AfFairs, 95Th Cong., 2d Sess., Report on INTERlocking DiRectorates AMONG the MAJOR U.S. CoRpS. (Comm. Print 1978) (the nearly 1000 page report is comprised primarily of printouts of individual director affiliations and corpo- 
empt ${ }^{121}$ from the Clayton Act. Should the Supreme Court overturn Crocker, for reasons noted im the foregoing discussion on the use of the Sherman and FTC Acts, a legislative response is similarly desirable. Because of the recent innovations in financial markets, ${ }^{122}$ the Clayton Act, the FTC Act, and the Sherman Act are ill-equipped to deal with bank-nonbank director interlocks as none of the Acts are attuned to the specific considerations of bank-nonbank relationships. Such relationships may well result in anticompetitive market effects. The reversal of Crocker by the Supreme Court would be a signal to Congress of the need for legislation dealing with bank-nonbank competitor interlocks.

Dean H. Blythe

rate board compositions, and is a testament to the massive number of interlocking directoratcs in corporate America).

As one commentator has noted concerning government reluctance to prosecute under section 8, "the Government's attack on corporate interlocks under the antitrust laws has been conciucted with all the observable success and fervor that attended the major campaigns of the Italian army during World War II." Travers, supra note 14, at 822.

121. An analogous situation confronted Congress in 1978. A decision had been rendered the previous year declaring bank-savings and loan imterlocks illegal. In re Perpetual Fed. Savings \& Loan Ass'n, 90 F.T.C. 608 (1977), vacated on other grounds, 94 F.T.C. 401 (1979). These interlocks had been regarded as Iegal, as attested to by the pervasiveness of the relationships. See supra note 93. Congress responded through a two step process. First, it passed the Depository Institution Management Interlocks Act (DIMIA), an intricate piece of legislation specifically attuned to and regulating bank-savings and loan interlocks. 12 U.S.C. $\S \S 3201-07$ (Supp. IV 1980). Again, a similar act could be tailored to the specific needs of the bank-nonbank area. DIMIA also granted banks and savings and loans a ten year period for compliance. Id. $\S 3205$. Congress provided this transition period to ease the upheavals resulting from the change in directorates mandated by the Act. A similar congressional response in the bank-nonbank area is desirable.

122. See supra notes $64-67$ and accompanying text. 